\title{
Perceptual Realism and Embodied Experience in the Travelogue Genre
}

\author{
By Perla Carrillo Quiroga*
}

\begin{abstract}
This paper draws two lines of analysis. On the one hand it discusses the history of the This paper draws two lines of analysis. On the one hand it discusses the history of the travelogue genre while drawing a parallel with a Bazanian teleology of cinematic realism. On the other, it incorporates phenomenological approaches with neuroscience's discovery of mirror neurons and an embodied simulation mechanism in order to reflect upon the techniques and cinematic styles of the travelogue genre. In this article I discuss the travelogue film genre through a phenomenological approach to film studies. First I trace the history of the travelogue film by distinguishing three main categories, each one ascribed to a particular form of realism. The hyper-realistic travelogue, which is related to a perceptual form of realism; the first person travelogue, associated with realism as authenticity; and the travelogue as a traditional documentary which is related to a factual form of realism. I then discuss how these categories relate to Andre Bazin's ideas on realism through notions such as montage, duration, the long take and his "myth of total cinema". I discuss the concept of perceptual realism as a key style in the travelogue genre evident in the use of extra-filmic technologies which have attempted to bring the spectator's body closer into an immersion into filmic space by simulating the physical and sensorial experience of travelling. Such technologies can be described as tri-dimensional, surrounding, immersive, kinaesthetic and stereoscopic. Moreover, I discuss the extent to which these technologies can be considered haptic, ocular or embodied, while referring to Laura U. Marks' notions of haptic visuality and haptic images.
\end{abstract}

Keywords: Bazinian realism, cinematic experience, embodiment, phenomenology, travelogue film

\section{Introduction}

The travelogue has brought to generations of spectators images of places and cultures from around the world, offering the experience of travel through the cinema screen. From the phantom rides of early cinema such as The Hale's Tours and Scenes of the World ${ }^{1}$ to today's IMAX 3D travel films, the travelogue has been discursively related to the practice of tourism, in the sense that both are grounded on a logic that conceives the act of seeing as a way of knowing a place (Urry, 1990). The activity of travel defined as the human action of movement across physical and geographical space implies the re-working and internalization of lived space through the senses. The experience of travelling is constituted by the visual apprehension of spatial changes as well as a kinaesthetic perception, and is enriched by the other senses, such as smell, touch and taste. Perception is an embodied process, as the human body allows sensuous perception to be anchored in a subjective position even if it confronts changing spatial surroundings. The process of perception during the experience of watching a film is also embodied, which turns the spectator into a voyageur, "a passenger that transverses haptic and emotive terrain" (Bruno, 2002, p. 16). In this way, cinema becomes a sort of

${ }^{*}$ Professor, Universidad Autonoma de Tamaulipas, México.

${ }^{1}$ Built in 1904 by engineer George C. Hale. 
transport method for the spectator to travel across different spaces (Soltani, 2008, p. 8). This dynamic is especially relevant to the travelogue film genre. For Anne Friedberg, the capacity of cinema spectators to travel in space and time has been partly responsible for the postmodern condition, described by Jean-François Lyotard, Frederic Jameson and Jean Baudrillard (Friedberg, 1991, p. 420). The detemporalization of the post-modern subject has brought on its fragmentation and loss of identity. According to Friedberg this has been caused, mainly by the mobilization of the subject's gaze, its technologically enabled capacity to wander, perceptually across multiple places in a sort of global flânerie. This mobilized gaze became active in different scenes, through architecture, the arcades, the activity of window shopping, the industrialization of transport and tourism, the exacerbated production and reproduction of images in photography and film. But perhaps one of the most evident examples of mobility of the gaze in the post-modern era is the travelogue film.

Travelogue films are non-fiction films structured around a journey and are usually narrated in first person. The word travelogue is often used in relation to the illustrated travel lectures of the Victorian era and the phantom rides of the cinema of attractions (Gunning, 2000). Although the travelogue film is not a form exclusive to documentary form, nor to a time period in film history, it can be found in different periods and styles encompassing a wide range of themes and subjects, such as cultural practices, religion, ethnography, anthropology, tourism and nature. It has been produced in the form of essay films and diary films as well as experimental, art house and home videos, using different voices and narrative styles that go from classic documentary to first person, subjective, auto-biographic and confessional styles. The travelogue is also the basic structure of IMAX documentaries (Griffiths, 2006, p. 242). Although it is a multifaceted form, there are two traits found in most travelogue films. First, they construct a mode of spectatorship that involves the perceptual simulation of travelling. This occurs in two different forms. On one hand, the hyper-realistic travelogue attempts to reconstruct the perceptual experience of travelling through a simulation of external sensorial stimuli such as stereoscopic technologies and large, panoramic screen formats. On the other, the autobiographic travelogue seems to express the internal perceptual aspects of the travel experience, such as subjective camera viewpoints, voice over, reflexive narration and in some cases an anthropomorphic camera language. This has to do with the progressive shift in documentary filmmaking towards introspection and subjectivity (Bruzzi, 2006, p. 4). Second, most of them use an episodic narrative, characterised by a succession of scenes linked together through the journey, often arranged chronologically, forming an itinerary and following a clear ordering of geographical points. An exception to this rule would be experimental travelogue films ${ }^{1}$, which tend to break with the chronological ordering and the itinerary structure.

\footnotetext{
1 Films such as Lisl Ponger's "Passagen" (1996), "Gone Troppo" (1984) by Nicholas Nedekopoulos, Joram Ten Brink's "The Man Who Couldn't Feel and Other Tales" (1997), "Motel to Motel" by Ryan Stec and Véronique Couillard, "400 Series" by Leslie Peters, Fern Silva's travel films such as "Sahara Mosaic" (2009) and "In The Absence of Light, Darkness Prevails".
} 
Phenomenology offers a useful framework to understand the perceptual process at work during the cinematic experience. A phenomenological approach to spectatorshipcan demonstrates that spectators engage at an embodied level with the places and spaces on screen. In film studies, theories on the embodied nature of the cinematic experience suggest spectatorship is not reduced to audio-visual perception but is extended across our sensing bodies, in a dynamic way between and across all the senses (Sobchack, 1992; Buck-Morss, 1994; Marks, 2000; Bruno, 2002; Massumi, 2002). Moreover, recent developments in the application of neuroscience to film studies have confirmed what phenomenologists claimed about the experience of watching a film. Namely, those cinema spectators internally and mimetically re-enact what they see on screen $^{1}$ (Gallese, 2005; Gallese and Guerra, 2012). New interdisciplinary studies such as neurophenomenology and neuro-cinematics have brought forward questions about the structure of human experience in an increasingly media-saturated world (Varela, 1996). According to Vittorio Gallese and Michele Guerra, the experience of space through film works in the same way that the experience of space in real life, that is, at an embodied level (Gallese and Guerra, 2012). The discovery of mirror neurons and embodied simulation mechanisms explain the ways in which spectators empathise with film (Gallese, 2001; Gallese and Sinigaglia, 2011; Gallese and Guerra, 2012). These approaches elucidate on the spectator's experiences and sensations, for instance the way they feel affected by camera movements and the ways in which they perceptually tune into filmic space.

\section{The Evolution of the Travelogue Film and Bazin's Teleology of Cinematic Realism}

The connection between realism and the travelogue film goes beyond its categorization as a documentary form and has to do with the stylistic conventions used to represent the human experience of movement in the cinema. Since its emergence in early cinema, travelogue films have been about recreating the perceptual experience of travel. Phantom ride films such as the Hale's Tours and Scenes of the World showed footage of travel along with moving seats and in some cases, aromas dispersed in the theatre complemented the spectacle. The impulse to recreate natural human perception through visual media is also evident in the $19^{\text {th }}$ century stereoscopic travel imagery, which attempted to imitate spatial perception through tri-dimensional images (Crary, 1992). These attempts can be described as a mimetic impulse in the history of the travelogue film. Advances in digital film technologies such as IMAX and IMAX 3D have rendered the history of the

\footnotetext{
${ }^{1}$ The discovery of mirror neurons in neuroscience confirmed many of the views proposed by phenomenologists about the role of the sensing body in the process of perception. Vittorio Gallese, a neurologist specialised in action perception and cognition, is one of the main proponents of a neuroscience approach to the study of film experience. Gallese describes mirror neurons as premotor neurons that are activated in our brains both when an action is performed and when it is observed being performed by someone else, whether on real life or on-screen (Gallese, 2005). Gallese asserts that this mirror mechanism is a form of embodied simulation, a mechanism in which one empathizes with the sensations and feelings that are being watched.
} 
travelogue film a progression towards increased realism, which corresponds with André Bazin's writings in his essay "The Myth of Total Cinema" (1967a). Bazin's ideas on the increasing realism of the visual arts that culminated with the mechanical reproduction of reality in photography and film have put into context the relationship between screen media and reality. Since the emergence of digital film and video, film theorists have argued about the confrontation of Bazinian film theory with technologies such as a 3D IMAX and virtual reality. Digital technologies have reframed the definition of realism. On one hand, the emergence of digital film and video signalled the disappearance of the indexical properties of film as a material record of reality. On the other, the digital manipulation of film in post-production has prioritised the simulation of constructed realities that are independent from their referents.

The relationship of the travelogue film to realism can be expressed in two ways. The documentary basis of the travelogue film means it always simulates an elsewhere that can be physically located in reality. Travelogue films portray places that exist physically in the world and are materially and spatially constituted. As a genre, the travelogue film has dedicated itself to develop a specific relationship with its audience. It has worked as a point of access to multiple locations, within a diegesis ascribed entirely to a factual world. At the same time, it has contributed to the visual mapping of the world for over a century, being a pivot in the production of discourses and myths about the far-away, the cultural other, the exotic and the notions of discovery, exploration, adventure and the unknown. On the other hand, travelogue films can also be defined as constructed realities that simulate virtual spaces that appear immediate, right at hand. Dudley Andrew describes the immediacy of the cinematic image,

In the great volume of a dark theatre the spectator gazes at and reflects upon images that relay a world that is both elsewhere and present in its visual trace. (2004, p. xvii)

Although film might seem immaterial, in the sense that its projection is constituted by light and digital impulses, it constitutes a part of a real, situated world. The virtual projection of images, whether on film or across media platforms constitute a key part of today's perceptual experience. They appear both immediate and immaterial. Steven Shaviro asserts that we now live in a world of simulacra (2007, p. 66). Film theorists have argued for over two decades about the relationship between reality and representation. A common stance tells us that realities portrayed in documentary films -albeit they hold a closer relation to reality than fiction film- can only be seen as subjective interpretations constructed by the filmmaker (Heider, 1976; Bruzzi, 2006; Staples, 2006). Theorists like Gabriel F. Giralt argue that reality is no longer something to be captured but something to be constructed $(2010$, p. 3). The postmodern experience of the world is only available through the spectacle of visual media, in which truth is no longer at stake but perceptual credibility through immediate appearances. For the fragmented, postmodern subject, the notion of reality has become elusive and variable. However, advocates for the representational power of documentary film argue otherwise. Stella Bruzzi (2006) writes: 
Repeatedly invoked by the documentary theory is the idealised notion, on the one hand, of the pure documentary in which the relationship between the image and reality is straightforward and, on the other, the impossibility of this aspiration. (p. 5)

In her seminal book New Documentary, Bruzzi reminds the reader that reality does in fact exist and it can be represented on film (Bruzzi, 2006, p. 5). Similarly for Bazin reality was something that could be captured and imprinted on film. His ideas on the progressive realism of the visual arts that seem to culminate with the invention of the mechanical reproduction of reality in the cinema appear even more enticing when framed in the context of hyper-realistic technologies, such as megapixels in digital photography, full and ultra HD (high definition) and escalating pixel rates ${ }^{1}$ in digital film as well as immersive, high resolution formats such as IMAX films. Film technologies are increasingly realistic in the sense that they offer higher definition, better sound fidelity and more sophisticated attempts to recreate reality than ever before. Bazin's teleology of cinematic realism in "The Myth of Total Cinema" (1967a) resonates with these technological advances and calls into question not only the evolution of cinema and its language but the ways in which spectators inhabit filmic worlds in the digital age.

The travelogue film is a form of documentary because it portrays a world that physically exists. However, its relation to reality is not just about its representation, or in Louise Pouliot and Paul S. Cowen terms, to its factual realism ${ }^{2}$ (2007, p. 244). Its different relations to reality and realism can be observed in three main categories which refer to styles and modes of production in the travelogue film genre, each of one ascribed to a different form of realism. The first and most relevant in relation to Bazin's ideas on the teleology of cinema is the hyperrealistic travelogue. This form is related to a perceptual form of realism. The hyper-realistic travelogue includes early travel rides such as the Hale's Tours of the World, IMAX and IMAX 3D travelogue films. This type attempts to recreate embodied experience through cinematic language. Their perceptual realism reaches its zenith in extra-filmic technologies ${ }^{3}$ that stimulate the spectator's senses and simulate a higher degree of immersion into filmic space.

The second form of travelogue film is the first person film, which can be associated to the conception of realism as the articulation of authenticity and the enunciation of personal narratives. The first person voice in travelogue films -and videos confers a degree of authenticity in its mode of narration that turns private experiences into public ones. These films are realistic in the sense that they express real voices which tell real stories lived by real people. Autobiographical, first person narration has defined the travelogue genre throughout its history. Since its

\footnotetext{
${ }^{1}$ One of the most recent developments in cinema technology is Lytro Cinema, cameras with 755 megapixels that can record up to 300 frames per second.

2 According to Pouliot and Cowen, the concept of realism perception has two sides, the factual aspect which corresponds to whether the events depicted on the film exist in the "real world" and the degree to which the events are plausible or convincing (2007, p. 244).

${ }^{3}$ I refer to extra-cinematic technologies as external devices to the audio-visual stimuli involved in film. Examples are moving seats, aromas, lights in the theatre or wind simulation in 3D and 4D theatres.
} 
emergence as a literary form, the narrative of the travelogue was characterised by being personal, episodic, diary-like and independent from a plot or a narrative progression (Ruoff, 2006, p. 11). The first person voice was an essential part of the Victorian travel lectures, which were narrated by the lecturer himself. Travelogues of the Victorian era were characterised by the live performance of the traveller, who narrated the story while showing photographs and short films to illustrate it. The lecturer was an important part of the attraction, even more so than the subject matter (Peterson, 2013, p. 24). The live, first person narrative helped construct the travel lecturer as a public persona and gave the stories an authentic character (Peterson, 2013, p. 24). The first and most recognized travel lecturer is Burton Holmes, who introduced moving images into his shows in 1898 (Ruoff, 2006). A decade later, the narration began to separate from the live speech of the lecturer and was incorporated into the diegesis of the film in the form of inter-titles (Altman, 2006, p. 76). By the 1930s, the emergence of synchronized sound technologies in the cinema allowed filmmakers to record their voice over the films. Although the physical presence of the traveller disappeared from the spectacle, the dynamic of showing and telling would become a ubiquitous technique in documentary films. The personal narrative would continue to be a staple of the travelogue film throughout its history and would disseminate to the present day in contemporary digital media. This is evident in the proliferation of home and tourist videos in social media. The first person narration is also present in subjective and essayistic travelogues, which recreate not just the sensorial dimension of the travel experience but the personal world of the filmmaker. Films such as Agnes Varda's Les Glaneurs et la Glaneuse (The Gleaners and I, 2000), Chris Marker's Sans Soleil (Sunless, 1983) and Lettre de Sibérie (Letter from Siberia, 1957). The voice-over in these films portrays the internal world of the narrator and exposes a more reflexive approach than traditional travelogue films. These films seem to recreate the visual field of the filmmaker through subjective camera viewpoints, providing a point of access not only to travel destinations but into their personal, embodied world. Some subjective travelogues take a step further in the representation of personal space and body language, such as Aleksandr Sokurov's Elegiya Dorogi (Elegy of a Voyage, 2001) which adopts an anthropomorphic style in terms of camera movements, to imitate the motion of a human body.

Third, the travelogue made in the style of the traditional documentary can be related to a factual form of realism. After the dissemination of John Grierson's style of documentary (2002), the travelogue moved away from its autobiographical character towards more impersonal approaches, such as the voice-over narration and fly-on-the-wall viewpoint. This style of documentary seemed to portray reality from an impartial viewpoint, and was perceived as truthful and objective. However, its authority to represent reality was challenged during the latter half of the $20^{\text {th }}$ century, which witnessed a shift from observational methods to self-reflective approaches in documentary film. This category of travelogue films is the most widespread in the travel documentary series and films produced for television networks such as BBC, BBC Earth, National Geographic, Discovery Channel and History Channel. It presents a 
classic documentary narration, often in third person and attempts to present an impartial, objective approach based on the public communication of science. These travelogues tend to represent the voice of objective, scientific knowledge and are associated with a factual form of realism, the representation of real events and places. This category includes early footage of cities without narrative intervention as well as some ethnographic and anthropologic travel documentaries.

\section{Towards a Phenomenology of Travelogue Films}

The debate around the concept of realism is rooted in the philosophical question of what can be considered real and what constitutes reality. It points at the tension between subjective perception or the conception of reality as something we can only know through our senses and the notion of reality as material, tangible and concrete. The difference between ontology (theory of being) and epistemology (theory of knowledge) points at the idea that a reality independent from the mind exists (Wikgren, 2005, p. 12). In phenomenology, the conceptualisation of the world as subjectively lived is explored in the concept of Lebenswelt by Edmund Husserl (Husserl, 1973). It refers to reality as a world of shared meanings and inter-subjective perceptions; it is the background, or rather, the horizon of human experience. Husserl's phenomenology conceived of the world as one made of phenomena, of appearances, and also conceived the nature of reality as subjective, perceptual experience (Bruzina, 2012, p. 225). Husserl is known as the originator of the phenomenological method, one of the main achievements of his work was the concept of intentionality, which refers to the nature of consciousness as a correlational structure ${ }^{1}$ (Husserl, 1973; Sartre, 1956; Heidegger, 1962, Sobchack, 1992). According to Husserl, intentionality is located in a transcendental ego, something that Maurice Merleau-Ponty would dispute in his work Phenomenology of Perception (1962). The work of Merleau-Ponty agrees with Husserl's idea that intentionality is the correlational structure of consciousness, although he argues that intentionality is not located in a disembodied and transcendental subject but rather in an embodied, situated, perceiving subject (Merleau-Ponty, 1962; Sobchack, 1992, p. 39). For Merleau-Ponty the correlational structure of perception is not a static process between noesis and noema, but a dynamic structure meaningful to embodied subjects that exist both spatially and temporally (Merleau-Ponty, 1962). For Merleau-Ponty, human movement is one of the most basic forms of intentionality; he argues that consciousness is being through a mediating body that directionally extends its attention towards an object. These

\footnotetext{
${ }^{1}$ Husserl's developed a model for the analysis of perceptual processes. The method involved the bracketing (also known as phenomenological reduction) of presuppositions and natural attitudes towards an object in order to reveal its "essence". Husserl's famous phrase: "to the things themselves" refers to this idea (Husserl, 1960, p. 12-13). By separating the acts from the objects of consciousness, Husserl's reductions involve three phases: the epoche, the eidetic reduction and the total bracketing. In this last stage the lived-world (lebenswelt) is isolated and the only thing that remains is consciousness itself (Sobchack, 1992, p. 37). In Sobchack words, what is left is "the correlation of intentionality, the structure of consciousness extending towards the specific phenomena" (Sobchack, 1992, p. 37).
} 
ideas are evident in his book Phenomenology of Perception (1962), which largely focuses on the performative dimension of the body through perceptual processes. Phenomenology as part of existential philosophy has been largely criticised from the 60s onwards for carrying the burden of liberal humanism with its essentialist and idealist approaches that failed to situate its analysis in historical and social contexts. However, recent debates in film theory have been grounded on a retake of phenomenology as means to theorize the body as a site of both perception and signification. A basic epistemological problem with the application of phenomenology in film studies is its attempt to equate the conceptual framework of a phenomenology based in human perception, with a phenomenology of film. The question of how is phenomenology applied in film studies deals with the confrontation of two modes of perception, namely human and filmic. This can be seen in the work of Vivian Sobchack and her appropriation of Merleau-Ponty's phenomenology of perception into film theory (Sobchack, 1992).

The re-emergence of phenomenology in film theory seems to react against the traditional analyses of film based on structuralism and psychoanalysis, as in the work of Christian Metz or Jean-Louis Baudry (Sobchack, 1992). In fact, the tension between structuralism and phenomenology can be traced back to the writings of Bazin, who was heavily influenced by the phenomenology of JeanPaul Sartre. Bazinian phenomenology of film faced severe criticism after 1968, at a time when the dissemination of the structuralist project influenced a large body of work in film criticism. As a response to the political upheavals of the time, structuralist approaches were more interested in analysing the social aspects of film rather than its aesthetics. The phenomenological assumption of reality as something perceived through direct experience was especially problematic for the structuralist approach. In contrast to structuralism, the recent retake of phenomenology in film studies has attempted to analyse signification in the cinema as a lived-phenomena, embodied in a subject of vision that is anchored in the world as it is experienced and perceived (Sobchack, 1992). Traditional analyses of film, such as the structuralist and the psychoanalytical approach tend to describe the film experience as "monologic", often treating the spectator as a material receptacle (Sobchack, 1992, p. 271). On the other hand, the phenomenological approach on the cinematic experience involves the conception of a dynamic form of spectatorship, in the sense that it conceives the spectator not as a passive recipient of images, but as a sensing, being dynamically engaged with the experience of film.

\section{André Bazin's Realism}

Although Bazin constantly wrote about realism in films, his views on the relationship between reality and film can be seen as pragmatic rather than fixed into one single conceptual model. Bazin's realism stems from the resemblance of film to natural perception. Some of his ideas were clearly inspired by existential phenomenology such as the participation of the subject in the construction of reality and the notion of reality as subjective perception (Rosen, 2003, p. 43). In other words, Bazin conceived reality as knowable only through perception 
(Andrew, 1973, p. 64). Rosen writes: "For phenomenology, the subject's relations toward "exteriority" are definitive, and Bazin can almost always be read as analysing the status of the objective for the subject" (2003, p. 44). In this sense, according to Bazin reality can only be known through the intentionality of a subject. Bazin also thought reality was something that could be recorded on film and something that could also be emulated through aesthetic style and cinematic techniques. He privileged long shots and in depth photography as stylistic devices that recreated a more faithfully perceptual reality. Bazin was also critical of montage because it altered what he considered the automatic recording of reality (1967b). A heavy use of montage in a film meant it was overtly fabricated because editing altered the natural duration of time, something he also valued. In "The Evolution of the Language of Cinema" (1967b) Bazin writes that the composition in depth, or the arrangement of a scene into multiple planes, allows a replacement of montage and expresses "respect for the continuity of dramatic space and, of course, of its duration" (1967b, p. 34). Duration is an element that reveals time as it is lived and therefore can be more faithful to reality. For Bazin, the depth of field changes the way spectators relate to film, making filmic representation more natural or more similar to the continuity of human perception outside the cinema. It can be seen how Bazin's ideas come from an observation on perceptual processes and the similarities between natural perception of the world, understood as physical, material spaces in which the body is sensorially anchored and the perception of, or rather through filmic space. In natural human perception whole scenarios can be apprehended within our visual fields opposed to the cropping of frames that necessarily occurs in the cinematic experience. Outside the cinema, perceptual experience is simultaneously visual(and aural) as well as spatial. This means perception renders multiple spatial planes which change according to bodily position and movement. This can be mimicked - only to an extent - through cinematic language by in depth photography. By providing several planes to look at, spectators get a sense of ambiguity and can choose where to focus their attention, something that also occurs in natural perception.

A key idea in the analysis of Bazin's ontology of cinematic realism is the evolution of technology in the cinema. The history of film is a history of discontinuity, made of multiple practices. Jean-Louis Comolli criticises the tendency in film studies to write film history in terms of its emergences, its first appearances (Comolli, 2015, p. 425). I argue that the technological basis of cinema necessarily involves the constant discovery of new technologies as well as techniques that constantly change the way films are produced. The transformation of film technologies and film language has also transformed modes of spectatorship throughout film history. Therefore, it is necessary, in order to understand any current practice, to trace back its origins and locate the discourses from which it emerges. Comolli argues that the analysis of a technical process, cut off from its context, (i.e. the first tracking shot, or the first close-up) isolates it from other contextual practices and automatically turns it into a historical object (Comolli, 2015, p. 430). The reasoning behind this idea is the conception of cinema, and for that matter, of any cultural practice, as the result of a social and economic context. For Comolli, every technique in the cinema is first and 
foremost, ideological. He argues that the social and economic conditions that shape a particular technique regulate its functions and meanings (Comolli, 2015, p. 431). This approach was a common stand during the 1970s, at a time when the politics upheavals after 1968 still reverberated in theoretical positions across the Humanities, which bred a tendency towards the post-structuralist project. In Comolli's view, the natural realism ascribed to film is the result of a process of codification, an example of this is the illusion of depth. He discusses the use of lenses with a medium focal length used in the first 20 years of cinema, he writes:

What we have to ask ourselves, therefore, is precisely why only these "medium" focal lengths were used during the first twenty years of cinema. I see no more pertinent reason that the fact that they restored the spatial relationship which corresponded to "normal vision" and that they therefore played their role in the production of the impression of reality to which the cinematograph owed its success. These lenses themselves were thus dictated by the codes of analogy and realism (other codes corresponding to other social demands would have produced other types of lenses). (2015, p. 433)

For Comolli cinema is an ideological instrument set to reproduce reality as visual experience. He considers depth of field as one of the determining factors regulating this reproduction of perceptual reality (Comolli, 2015, p. 434). During the first decades of cinema, the dominance of film studios meant films were produced indoors, which relegated depth of field photography as an ornamental feature to show a landscape in the background (Comolli, 2015, p. 438). Comolli writes that the incorporation of lenses that could display further depth had to do with the desire to identify and recognise the cinematic image with the image of "life itself" (1980, p. 129). For Comolli, every advance in technology is not merely technical but ideological, and in the case of the cinema these advances correspond with an interest in realism (1980, p. 131).

Conversely for Dudley Andrew, the main idea at the chore of Bazin's theory of film is the "objectivity of the cinema" (1973, p. 64). In his view, film is beyond subjective perception because it can work as a record of reality (Andrew, 1973, p. 64-65). However, Andrew insists this does not mean Bazin conceived reality as pre-existing, he writes: "In this view reality is not a completed sphere the mind encounters, but an "emerging-something" which the mind essentially participates in" (Andrew, 1973, p. 64). On the other hand, for Richard Rushton Bazin's theoretical positions have been overtly simplified throughout the years (2011a, 2011b). He summarizes the common interpretation of Bazin's ideas on realism in film studies:

In short, films should aim to reproduce the conditions of natural perception and, as a result, films will correspond with reality. All a filmmaker need to do is point a camera at the world, keep the camera rolling, and the result will be undeniably real, and, granted the time and space provided by depth of field and the long take, reality will be free to yield its beauty and mystery. (Rushton, 2011b, p. 42) 
Rushton argues that Bazin did not conceive of film as a representation of reality but rather conceived of cinema as reality itself (2011b, p. 44). However, the very notion of realism is based on a conceptual divide between the real world and its representation, even if paradoxically, these representations also constitute a part of reality. The idea of cinematic realism necessarily traces a frontier between the materiality of objects and things in the world and their appearance traced as film images. According to Rushton, if the cinema's task is to represent reality, then films are bounded to be copies or imitations of the pro-filmic world (2011b, p. 45). Bazin's "Myth of Total Cinema" (1967a) refers to that impossible point in which film appears just as real as the real world (Rushton, 2011b, p. 45). For Rushton, the impossibility of a complete and whole representation of the world is based on a logic that conceives of all media as inadequate to fully represent reality (2011b). This discourse also conceives reality as raw, pure, material and constituted prior to perception, unmediated and independent from the perceiving subject. For Rushton, the senses act as mediation between this raw reality and our brains, in a way that reality is always already mediated by sense perception (2011b, p. 46).

\section{Montage, Depth of Field and the Long Take in Travelogue Films}

In "The Virtues and Limitations of Montage" Bazin writes about the use of montage in documentary. According to Bazin, the object of the documentary film is to present facts to an audience which expects to see footage of events that naturally develop in front of the camera (Bazin, 1967c). The reconstruction of reality is justified in the case of didactic documentaries or documentaries about historical events which aim to illustrate rather than report events (Bazin, 1967c, p. 51). Bazin describes Nanook as a romanticised film, a type of film which derives its significance, partly from the "integration of the real and the imaginary" (Bazin, 1967c, p. 51).

However, we cannot assume that the travelogue genre subscribes to a Bazanian style of realism only because it tends to reconstruct reality through long takes and in depth photography. For Bazin the long takes and deep focus functioned to an extent, as narrative devices. In many travelogue films these techniques work as means to carry spatio-temporal continuity, independent from narrative progression. For instance, a main element of travelogue films is landscape photography, which involves the use of deep focus cinematography. The portrayal of spatial depth in the travelogue has more to do with landscape photography and with showing a sense of distance than serving a narrative purpose. In travelogue films, the narrative is often secondary to the visual display of places and to the visual simulation of movement across physical space. In depth photography is often used in the travelogue to convey the feeling of movement but not as a narrative device. For instance, the long tracking shots of IMAX 3D travelogues involve the apprehension of multiple visual planes from the perspective of a moving camera, but rarely serve the continuity of the narrative.

In "The Virtues and Limitations of Montage", Bazin discusses the use of in depth photography in Nanook of the North, specifically in the seal-hunt scene 
which shows the hunters on the shore pulling a seal trying to swim away (1967c). Bazin emphasizes the importance of respecting the "spatial unity of an event", which is both obvious and necessary (1967c). An event always involves a particular range of spatial relations, all of which should be captured in a single take if the filmmaker is interested in showing the whole event. In these cases, deep focus cinematography is not so much a matter of simultaneous narration rather than a question of size, of the actual space the action is occupying within the frame. The use of montage as a technique in cinematic language has shifted and evolved along the history of the travelogue film. Early travelogues from the cinema of attractions were mostly concerned with the recording of moving images and not with the narrative. This is the case of many archive reels from the early $20^{\text {th }}$ century, in which the novelty of the medium itself was the attraction. Examples of this are series of films such as Modern China (In Quaint Pekin, 1910), Nankin Road, Shanghai (1901), Old London Street Scenes (1903). Moreover, even when there was a need to supply some sort of continuity, travelogues of early cinema were not always consistent in terms of montage. For instance, the films exhibited in The Hale's Tours and Scenes of the World had no continuity in terms of camera viewpoint; shots recorded from the front of a moving image would be followed by shots recorded from the side of a train, or from static landscapes (Rabinovitz, 2006, p. 50). In this case the lack of montage worked against the extra-cinematic devices employed to provide the spectators a sense of realism. Moreover, IMAX travelogues have moved towards the disappearance of montage and the use of long tracking shots that illustrate the continuous flow of moving cameras, as aerial photography recorded from drones, helicopters and cranes.

One of the early uses of montage in travelogue films emerged with the need of representing the continuity of a character's journey in a narrative. In ethnographic travelogues, the use of a main character other than the traveller/filmmaker is a strategy used to represent the stories of cultural others. Films such as In the Land of the Headhunters (1914) by Edward S. Curtis and Nanook of the North (1922) by Robert Flaherty involved the recreation of cultural performances and its consequent fictionalization. In these films, montage was used to tie together the stories of the main characters -non-professional actors performing themselves. The production of ethnographic films has involved the articulation and description of cultural and racial others in an attempt to unveil new knowledge about non-western social groups through the representation of their ways of life, customs and rituals. The intervention of the director and the presence of the camera have effects which distort the realities they are trying to document, as in the Rashomon effect and the Heisenberg effect ${ }^{1}$. Nonetheless, at the time of their release, both Nanook and In the Land of the Headhunters were promoted as authentic accounts, no matter how staged or heavily directed the films were produced.

\footnotetext{
${ }^{1}$ Karl Heider writes about the Heisenberg effect, in which the presence of the ethnographer changes the behaviour of the subjects, and the Rashomon effect, in which the characteristics of the ethnographer or filmmaker affect the research (Heider, 1997, p. 84).
} 
The long take is an important part of Bazinian realism, mainly because the long duration allows scenes to unravel in their own time. In a sense, duration forces the spectator to witness time as it is lived. According to Tiago de Luca, the long take is a trend in world cinema that emphasizes the physicality of bodies and landscapes and is associated with a realism of the senses (2011, p. 43). Images of vast spaces are a key part of the travelogue film genre, something that is also present in genres such as the western and the road movie, all of which posses a close connection to landscape photography (de Luca, 2011, p. 46). De Luca refers to this style as "visionary realism", a form of realism that is not about copying reality but rather expressing the perceptual experience of it, its phenomenology (2011, p. 50). The term perceptual realism reflects a more inter-sensorial experience of film, rather than making a reference to a single sense. The long take in art house cinema and independent cinema is used as a counter-measure to the overtly stimulating live action scenes of Hollywood films. A slow, long take is a critical strategy against the pre-packed narratives of commercial Hollywood films. It presents an alternative way of inhabiting and perceiving filmic space and time. For de Luca, a typical example of a long take in world cinema is the lonely character wandering through a deserted landscape. He writes: "Devoid of psychological nuances, they interminably walk, stroll, and loiter, often aimlessly, precluding narrative interaction in favour of phenomenological and sensory experience" (de Luca, 2011, p. 43). The expression of contemplative mind-sets, loneliness and spiritual searches is visually materialised through the juxtaposition of the human figure against wide, open landscapes. These images symbolize the subject's internal disposition towards the world, an encounter with the greatness of vast spaces, and the fear and fascination that is provoked through its presence. These aesthetics of nature are reminiscent of Edmund Burke's ideas on the sublime and beautiful (1756). An aesthetic discourse often used by filmmakers exploring the experience of travel such as Peter Mettler's The End of Time (2012) and Picture of Light (1994); Aleksandr Sokurov's Elegiya Dorogi (Elegy of a Voyage, 2001), Wim Wenders' The Salt of the Earth (2014), Werner Herzog's science fiction travelogue Fata Morgana (1971), Encounters at the End of the World (2007), The Wild Blue Yonder (2005) and The Wheel of Time (2003).

\section{Factual Realism, Indexicality and Bazin}

For Bazin, the way light is imprinted on film is the most essential part of film's connection to reality. Although he never used the term, the indexical quality of the photographic image was a key point in his conception of the mechanical reproduction of an objective reality, which for Bazin, allowed the world to be captured on celluloid. In "Ontology of the Photographic Image" Bazin wrote: "For the first time an image of the world is formed automatically, without the creative intervention of man" (1967d, p. 13). He stated that photography had freed the plastic arts from their obsession with likeness, with realism and delivered an objective proof of reality as something reproducible (Bazin, 1967d, p. 16). It is precisely in this thinking when it becomes evident that for Bazin, reality belongs to a different category than the cinematic image. Bazin believed there was a basic 
incompatibility between the space represented on film and the space we live in (1967e, p. 108). According to Dudley Andrew, Bazin's ideas on the nature of reality were not entirely consistent (1973). While he did borrow some notions from the phenomenologists of his time, such as Sartre and Merleau-Ponty, he did not entirely believe reality as something that exists only when a consciousness engages in perception $(1973$, p. 64). It was the frontier between the work of art conceived as a representation of the world and the world itself that served as a basis for Bazin's thought. Andrew writes: "The whole of Bazin's film theory can be derived from his faith in the mysterious otherness of external reality" (1973, p. 64). In recent decades, the emergence of digital technologies has made the indexical qualities of the photographic image disappear, along with its referent (Shaviro, 2007; Andrew, 2004). The dissemination of digital techniques for the manipulation of photography and film has meant the digital image is always manipulated, edited or animated (Andrew, 2004). The manipulation of digital film in post production have meant the creation of scenes and characters that appear credible to our eyes and can faithfully imitate the physical conditions of the world in terms of lighting, modelling of forms and sceneries, yet these objects do not necessarily exist in real life. This is what Bazin would call pseudo-realism in "The Ontology of the Photographic Image" (1967d). Bazin describes this as "a deception aimed at fooling the eye" (1967d, p. 12). Jonathan Friday (2005) writes:

To explore the ontology of the photographic image is therefore to explore how photographs present themselves to consciousness, and to reveal their nature by careful description of what they are for us in experience. (p. 340)

For theorists like Philip Rosen, realism in the visual arts is conceived as "the impression of visual likeness" and is seen as a step in the teleological development towards mechanical reproduction (2003, p. 49). In this sense, what becomes at stake is the credibility ascribed to the film image, its indexicality and its role as evidence of the pro-filmic event as a tangible reality (Rosen, 2003, p. 49). The indexicality of the image is as an "irrefutable testimony" of its image (Rosen, 2003, p. 49). However, Rosen asserts that the very core of the credibility ascribed to the indexical properties of the photograph is not the light imprint on the celluloid but rather the proof of the existence of the referent, its presence in the past and the testimony of how the sign was produced (2003, p. 50). In other words, it is the spectator's previous awareness of how the images came to exist that grants the film its factuality (Rosen, 2003, p. 51).

Bazin admired the connection of film with reality, its capacity to work as a witness of the pro-filmic event. For him, film was a record of reality like no other. He writes about the documentary Kon Tiki (1950), a film that records an expedition carried out in 1947 by Norwegian and Swedish scientists as they navigated for 4300 miles from Peru to the Polynesian islands in a balsa-wood raft. The goal of the expedition was to prove ancient Polynesians populated South America by sea migrations that crossed the ocean on wooden balsas. The explorer and leader of the expedition Thor Heyerdahl recorded the journey. He was an amateur filmmaker and many of the scenes were not framed properly. Bazin wrote: 
Yet somehow Kon Tiki is an admirable and overwhelming film. Why? Because the making of it is so totally identified with the action that it so imperfectly unfolds; because it is itself an aspect of the adventure. Those fluid and trembling images are as it were the objectivized memory of the actors in the drama. (1967e, p. 161)

Bazin was fascinated not by the content of the images but because they were "the photograph of the danger", which served as a witness to the authenticity of the expedition (1967e, p. 161). The camera captured the journey in its most concrete dimension, imprinting the materiality of real events. This idea of reality as objective and material was something that appealed to Bazin, and that he found in the aesthetics of Kon Tiki (Rosen, 2003, p. 44). However, the appeal of this form of documentary does not lie only in the indexical properties of film but rather in the immediacy of its visual style, in the illusion of witnessing the development of real events, untouched by post-production. It is a style characteristic of direct cinema films, which became popular with the development of portable, hand-held cameras. The film Maidentrip (2013) directed by Jillian Schlesinger presents a similar aesthetic. Maidentrip portrays the journey of Laura Dekker, a 13-year-old girl who sails around the world alone. Dekker uses a hand held digital camera to record her experience. In the film, she often talks directly to the camera as she narrates her impressions and daily struggles. It makes evident the primordial role of the camera as a tool to record the journey. The post-production of Maidentrip appears discrete and does not come across as overtly fabricated. However, the narrative structure that was given to the film in the editing room constructs the film as an adventure and lends a dramatic structure to asequence of hand held shots. Points of tension are emphasized while uneventful shots are summarised into shorter scenes. It is obvious that is a constructed version of the recordings. However, neither the post-production nor the fact that the film was shot with a digital camera lessens its factual realism.

\section{Bazin's Teleology of Cinematic Realism and the Travelogue Film}

Bazin saw the emergence of cinema as the culmination of a long-standing project in the visual arts that aimed at the complete mimesis of reality as it was experienced in human perception (1967a). Cinema achieved what no other medium did before: the photographic recording of movement through time by mechanically re-constructing spatial and temporal relations as they are experienced by the human eye (Shaviro, 1993). For Bazin, the myth of total cinema is nothing but the exact reproduction of reality, "an integral realism, a recreation of the world in its own image, an image unburdened by the freedom of interpretation of the artist or the irreversibility of time" (1967a, p. 21). Jonathan Crary notices that pre-cinematic optical devices from the $19^{\text {th }}$ century, such as the thaumatrope, phenakistiscope, stroboscope, zootrope, as well as the diorama, the kaleidoscope and the stereoscope are frequently discussed in film studies in terms of their progressive development towards a more perfect form of representation that culminates with the emergence of the cinema (1992). Crary also points out 
that such approaches tend to conceal the specific characteristics of each of these optical devices (1992, p. 110). Although there is a consistent relation between the emergence of optical and cinematic technologies and a progressive development towards increasingly realistic representations, each optical device or technology presents a different way of perceiving and a different relation to reality. There are three main aspects that best describe the perceptual realism of the travelogue film and the way it relates to Bazanian teleology of cinematic realism. The illusion of continuity, the kinesthesic properties of the moving image - more prominently when using moving cameras- and the immersive experience that larger screen and higher resolution formats provide.

From its emergence in the $19^{\text {th }}$ century, travel lectures were mimetically reproducing the itineraries of travel through linear structures based on episodic narratives that worked as an audio-visual re-enactment of the travel journey. The travel lecture's episodic narrative - usually arranged in chronological order provided a linearity to the otherwise unrelated images that resembled the trajectory and itinerary of the traveller. This continuity has remained consistent throughout the history of the travelogue. In fact, it would become primordial in the construction of narrative cinema. The continuity that renders the otherwise unrelated images of travel into a coherent journey-like structure is organized around a "logic of the visible", which creates a unity in the causality of events projected on screen (Auerbach, 2007). Its "diegetic unity", as Jonathan Auerbach suggests, creates an illusion of consistency between separate spatiotemporal moments which form- by virtue of suturing different shots- an imagined continuum distant from the event as it was filmed (Auerbach, 2007, p. 85). The articulation of spatiotemporal events into a continuum allowed the spectator to feel immersed within the filmic flow and perceptually re-enact the travel journey.

The introduction of moving images into early travel lectures ${ }^{1}$ opened the possibility of representing a crucial element of its subject matter: the movement across physical space. The magic lanternslide allowed the travel lecture to represent the visual field of the traveller as a moving gaze and provided the audience a new kind of perceptual illusion. Initially, the transition from lanternslides to moving images in Burton Holmes' travelogues did not produce any major changes in his shows, as they were shown only as supplements at the end of the lectures. In 1899 Holmes began to integrate the films into the lectures themselves (Musser, 1994). It was a source of wonder and excitement to the audiences of the $19^{\text {th }}$ century to witness the changing of sights from country to country in the course of one single show (Clarke and Doel, 2005). The films became part of the continuum of the narrative, visually re-constructing the journey. As new technologies of transport developed, this visual reconstruction would increasingly depart from the situated lived space of the traveller's body and move into the passing views as seen from moving vehicles. Railway travel was a central element of early cinema's chase films such as The Great Train Robbery (1903) by Edwin Porter and Romance of the Rail (1903) by Thomas A. Edison. The central attraction of films like Elevated Railway (1903) was the changes of

${ }^{1}$ In 1898 Burton Holmes introduced $60 \mathrm{~mm}$. short interludes of moving images to his travel lectures (Ruoff, 2006). 
perspective in ocular perception: the roofs seen from the top and the smooth displacement of the views passing by. The urban setting became a spectacle for the moving gaze of the camera, usually attached to the end of a train. An example of this is Panorama Exterior Westinghouse Works (1904). The film shows views of the city as seen from the railway but unlike the Elevated Railway, it not only shows the front of the train but the view from the sides. In Panorama Exterior Westinghouse Works the regular speed of the train's movement produces a visual rhythm in which electricity posts, buildings, roads, rocks and landscape features are experienced as a continuum. Schivelbusch suggests that the rapid and constant changing of scenery did not give the train traveller enough time to grasp the space as a whole, which meant the landscape could only be seen as fragments (1977). Visual experience from the train was fragmented also in the sense that the train traveller was continuously divided between the visual stream of passing views and the situated-ness of the body as anchored in the interior space of the train carriage, a split that resembles the experience of film itself.

The camera traversing space gave the spectator the sensation of moving along with the camera eye. It offered the visual apprehension of spatial references through a similitude to real life perception. One of the first uses of a moving camera in a documentary film was in 1899 when James Williamson, from the Brighton School recorded the Henley's regatta from a sailing boat (Gubern, 2014). The use of moving cameras in filmmaking helped create a necessary distance between the language of cinema and the theatre. Other examples of early moving cameras are Thomas Alva Edison's train travel films of New York subway Elevated Railway, 23rd Street, New York (1896) and 104th Street Curve, New York, Elevated Railway (1899), New York Subway also known as Interior N.Y. subway, 14th St. to 42nd St. (1905).

The recording of the constant unfolding of views allowed the cinema spectator to experience the sensation of movement by taking the position of a moving gaze. Jennifer Barker suggests that the pleasure found by the spectator in the cinema of attractions was derived from its kinetic properties, from the impression of movement itself and not from the narrative (2009). The cinema of attractions involved a mode of spectatorship in which the novelty of moving images was in it a source of pleasure and excitement (Barker, 2009, p. 133). One example is the famous and somewhat dubious case of the Lumière's film L'arrivée d'un train à La Ciotat (The Arrival of a Train, 1896) in which the terrified audience reacted to the image of the arriving train as if it was a real object moving towards them (Gunning, 1989). Tom Gunning writes: "According to a variety of historians, spectators reared back in the seats or screamed or got up and ran from the auditorium (or all three in succession)" (1989, p. 114). For Gunning, the visual power of such forms of entertainment was a matter of a trompe l'oeil $^{1}$ play between knowing it is an illusion yet feeling its uncanny resemblance to real life (1989, p. 80). The audience of the cinema of attractions performed an embodied response to the representational power of the image (Marks, 2002, p. 7). These immediate bodily responses were not confined to audio-visual perception

\footnotetext{
${ }^{1}$ Trompe l'oeil refers to a genre of hyper-realistic illusion in the arts. From French "trick the eye".
} 
but were meant to provoke kinaesthetic sensations. The prominence of its embodied response was later reinforced in the travel ride film, which emphasized the novelty of sensorial experience as a spectacle in which the body took a central stage (Rabinovitz, 2006, p. 45).

The travelogue film in the context of the visual arts seems to follow a history of attempts aimed at the mimicry of the embodied experience of lived space. This has involved different modes of representation to simulate sensorial immersion, often through the use of wide formats aiming to cover most of the visual field of the spectator. As other forms of realist representation in the $19^{\text {th }}$ century, the travelogue provided the sensation of physically being in another place. For instance, the panorama displayed views of landscapes that extended horizontally, covering as much visual space as the naked eye would cover. Either in the form of a flat depiction of a landscape or rolled inside a building that located the spectator at its centre (as in the panorama rotunda), the panorama allowed the viewer to feel immersed within the represented space. The spectator's eyes could linger through the extensive view in a similar fashion that one would do while looking around in an open space. These forms of photographic media, such as the panoramic and dioramic shows, were designed to substitute the still expensive train travel journey (Schivelbusch, 1977). In the $19^{\text {th }}$ century panoramas were also used as a replacement for the Grand Tour (Neumann, 2008). But unlike the panorama and the diorama, the travelogue film relied on its intrinsic relation to the moving image to convey a feeling of lived space. This mode of vision is still present in immersive formats such as the IMAX, which is reminiscent of the buildings of panorama rotundas. These immersive modes of vision are also connected to the extended representations of space present in the panoramic paintings of the $18^{\text {th }}$ and $19^{\text {th }}$ century. Cinematic technologies in the 1950s that used widescreen formats such as the Cinerama, Cinemascope ${ }^{1}$ and Vista Vision ${ }^{2}$ also relied on creating immersive visual experiences. Bazin makes a comparison between visual perception in Cinerama $^{3}$ and natural perception (2014). Bazin noticed that in Cinerama the angle of vision is 146 degrees, almost the 160 degrees covered in human vision (Bazin, 2014; Reeves, 1999, p. 87). This meant the spectator's visual field was almost completely filled with the cinematic image. For Bazin, the most important feature of this new technology was the enlargement of the screen (Bazin, 2014, p. 221). He writes:

What is so pleasing about Cinerama is the realism of its spectacle, realism so great that it sometimes edges into depth [relief]. But depth cannot very well reinstate realism, just as we have seen happen in the stereo-optical 3D films that the public has shown it doesn't want. What now? Can we say what realism is? I would define it essentially not by rendering of depth but rather of space. (Bazin, 2014, p. 222)

\footnotetext{
${ }^{1}$ Cinema Scope is an anamorphic, widescreen film format used from 1953 to 1967.

${ }^{2}$ Vista Vision is a widescreen film format created in 1954 by Paramount Pictures with higher resolution than $35 \mathrm{~mm}$. film.

${ }^{3}$ Cinerama is a panoramic, widescreen format developed in the 1950s. It originally used three projectors on a curved screen.
} 
For Bazin, the larger screen was a progressive move, especially for the documentary genre $(2014$, p. 223 ). A large format could not only recreate reality better because of its immersive view, but it also meant that for a factual genre such as the travelogue and the documentary, the audio-visual stimuli that is experienced in real life could be almost duplicated.

\section{Mimetic Re-Enactment of Sensorial Experience: The Travel Ride Film}

The phantom rides of the Hale's Tours and Scenes of the World incorporated a new set of hyper-realistic strategies to mimetically represent travel. Its hyperrealism involved the reconstruction of the travel journey not only as it appears to our eyes, but also as it feels to the senses. From the travel-ride films of early cinema such as the Hale's Tours, the Cinéorama, the Maréorama, the Odorama, and the Phantom Rides to the appearance of the Disney Star Tours and 3D IMAX pictures, representations of embodied experience were driven by the use of hyper-realistic and extra-cinematic technologies that attempted to bring spectators closer to a sensorial immersion in cinematic space. The cinematic properties of the travel ride and its portrayal of space through time granted the viewer a realistic experience by providing the visual illusion of travelling while picturing the constant flow of the landscape as objects moving towards the spectator (Rabinovitz, 2006). Lauren Rabinovitz points out that certain elements in the landscape heighten the rhythm of such flow (2006). For instance, it was common for the cameras in the front of the train to be tilted forward towards the train tracks, which formed a strong indicator of visual perspective and distance. Other examples are telephone poles, buildings, bridges and tunnels, which act as visual markers that change the rhythm of the trajectory, adding points of rest or breaks between light and darkness and creating a rhythm through repetition.

The Hale's Tours and Scenes of the World was designed as an artificial railway, in which a short film of approximately ten to fifteen minutes was projected (Fielding, 1970). The film usually showed the point of view from a moving train and it was projected in the front window of the train car which enhanced the sensation of travel while other machines made the illusion more convincing: the train car would tilt and shake and there were sounds of steam whistles and wheels (Rabinovitz, 2006). It was a set of hyper-realistic technologies combining auditory, tactile and visual sensations (Fielding, 1970). Barker associates the emergence of the moving image with other attractions such as the rollercoaster, which "offered a similar kinetic thrill" (2009, p. 132). If the cinema of attractions was closer to the rollercoaster than to other forms of cinema, the travel ride ${ }^{1}$ was the closest form to its kinetic re-enactment. Rabinovitz writes:

Across the century, travel ride films articulate a seemingly contradictory process for the spectator: they attempt to dematerialize the subject's body

\footnotetext{
${ }^{1}$ Raymond Fielding traces back the origins of the travel ride to 1895 , when H.G. Wells and Robert Paul patented a form of travel-ride film that simulated travel through time and space (1970, p. 34).
} 
through its visual extension into the cinematic field while they emphasize the spectator's body itself as the centre of an environment of action and excitement. They have to sensationalize and smooth over the gaps between the in-the-body experience (affect) and the out-of-the-body sense of panoptic projection. (2006, p. 45)

Perhaps the spectator's body was not necessarily split between vision and sensation, but rather the viewing of the film and the extra-cinematic stimuli complemented each other. The spectator's senses not only re-created the embodied experience of travel as presented by the film but also created its own. The travel ride's cinematic re-construction was based on an input/output logic of sensation that translated sensuous experience into a mechanized copy of embodied sensation. By attempting to recreate sensorial experience, the travel ride film translated sensation into a mechanical copy, in which each sense was separated from the others. Joint together, the sum of external stimuli compiled an organisation of the senses that forewent an affective and proprioceptive sensation. In that sense, embodiment became external and disintegrated from the unitary nature of sensorial processes. Affective sensation was not anticipated, as it cannot be controlled by external stimuli only. In the travel ride film, affect was not sensationalized nor smoothed over against an "out-of-the-body" ocular perception. Instead, it was embodied experience that was sensationalized as physical, predicable in its organization and mechanized, while affective experience remained dismissed. A representation of affective, or "in-the-body" experience of travel, as Rabinovitz puts it, would necessarily deal with the internalized connections between memory and sensuous experience. The travel ride film only incorporated different aspects of the sensorial experience of travel in a mimetic reenactment already divided into a set of fragmented stimuli.

This mechanized approach to sensation in the travel ride film contrasts with the emergence of subjective visuality in the $19^{\text {th }}$ century. Crary writes that during the $19^{\text {th }}$ century, there was a shift in the conception of vision and perception as grounded in the materiality of the body and not only dependent on external stimuli (1994). The emergence of subjective modes of vision meant perception was not as much about external stimuli but about the make-up of our sensorial experience as it is internalized. This shift marked an epistemological crisis in which perception could no longer be conceived as objective nor as the foundation of human knowledge of the world (Crary, 1994). Paradoxically, during the $19^{\text {th }}$ century, in philosophy as well as in the emerging field of scientific psychology, perception was made embodied, but also quantifiable, measurable and abstract. Reality was no longer conceived as something attained directly through perception; instead, perception began to be conceived as an internal process somewhat independent from an objective and material reality. The visual cultural regime brought by modernity reflected the merging of the subject's exterior and interior (Crary, 1994, p. 22). The travel ride film came into being from the intellectual climate of an epoch that conceived sensation as torn between input (stimuli) and output (embodied experience). This discourse ultimately conceived of sensuous stimuli as reproducible, abstract and mechanic. The premise was that although the subject 
experiences perception as an internal process, the stimuli that causes perceptual experience could be manipulated, measured and controlled. The travel ride film, in its attempt to recreate the sensation of movement, failed to recognize the variable changes intrinsic to the subjective, affective experience of sensing. The travel ride film simply took the fragmented components of a post-rationalized embodiment of the travel experience and turned it into segmented stimuli. Brian Massumi writes about the relationship between movement and sensation:

Feelings have a way of folding into each other, resonating together, interfering with each other, mutually intensifying, all in unquantifiable ways apt to unfold again in action, often unpredictably. (2002, p. 1)

For Massumi, the relationship between sensation and movement is unpredictable change. He suggests that previous conceptions of movement as literal, predictable and mechanic have already fallen into forms of "naïve realism" (Massumi, 2002, p. 1). In that sense, the technologies involved in the travel ride conceived the sensation of travel as homogenous throughout the audience and, as Massumi asserts, it naively imagined sensation as reproducible. However, the reenactment of bodily sensation in travel ride films is not entirely consistent in its continuity. Clarke and Doel suggest that although the hyperrealism of travel ride films was in fact derived from the technologies used, the content of the films was often not explicitly realistic (2005). In the sense that some travel ride films included incongruous elements that threatened the continuity of the illusion, such as tracking shots followed by still shots or static viewpoints of landmarks (Clarke and Doel, 2005). Arguably, the weight of "truth" that the travelogues of early cinema carried was to be displaced by a realism derived from pure "sensation". While the travel ride films of early cinema focused on travel and tourist experiences, contemporary travel rides increasingly depict fantasy themes, science fiction characters and trips to outer space or ancient civilizations (Rabinovitz, 2006). Examples of contemporary ride films are Transformers: The Ride 3D (2011), Star Tours: The Adventure Continues (2011), Star Trek: The ExperienceBorg Invasion 4D (2004) and Escape from Dino Island (1998). These travel rides articulate a hyper-reality that is primordially about producing credible sensorial simulations. It is a perceptual form of realism rather than a fact alone, and as such it is no longer connected to truth or veracity. It does not matter if what the spectator sees exists outside the cinema as much as it matters that the sensorial stimuli are credible to the spectator's senses that is realistic as opposed to real.

\section{The Travelogue and the IMAX Screen}

Travelling is intrinsic to IMAX forms of representation and it is also inscribed in its promotion and exhibition contexts (Griffiths, 2006). Alison Griffiths notices that the travelogue constitutes the structural principle of IMAX films (2006, p. 239). This is evident in IMAX's visual surveillance of space, characterised by a 
heavy use of aerial photography and phantom rides ${ }^{1}$ in which long tracking shots seemingly cut across vast spaces (Acland, 1998; Griffiths, 2006). The camera penetrates into corners of the landscape unfolding spectacular views into camera movements that are otherwise unattainable for human visual perception. In fact, a dominant discourse in the promotion and exhibition of IMAX documentaries is the presentation of IMAX films as cinematic journeys, and the appeal of watching films so realistic that provide the sensation of actual travelling. This is due to the kinesthesic sensation provoked by cameras moving rapidly across heights (Acland, 1998). Sweeping camera movements added to the gigantic proportions of the IMAX screen provoke in the spectator a sensation of being "inside" the film, providing a panoramic mode of vision that causes the spectator's immersion into filmic space (Acland, 1998; Recuber, 2007). IMAX sound technologies are promoted as perfectly tuned sound, laser aligned audio-placement and pristine sound accuracy. Their images are promoted as offering un-paralleled brightness and clarity, heightened realism delivered by reflective screens and an immersive experience with the highest resolution and highest quality in tri-dimensional images $^{2}$. An example of travelogue films on the IMAX screen is The IMAX Ultimate Collection, a series showcasing destinations around the world in each episode. It was produced for exhibition in IMAX theatres and later adjusted for television broadcast. The series include The Alps (2007) by director Stephen Judson, Greece: secrets of the past (2009) and Coral Reef Adventure (2003) by Greg MacGillivray, amongst many others. Moreover, the production company MacGillivray Freeman specializes in adventure travel documentaries, some of which produced especially for IMAX 3D such as Journey to the South Pacific (2013), Grand Canyon Adventure: River at Risk (2008), To the Arctic (2012) and Everest (1998), all directed by Greg MacGillivray.

The aerial photography we find in most of these travelogue IMAX films allows an unprecedented continuity of visual perspective. Films such as The Alps (2007) use a flying camera that covers vast spaces, offering panoptic landscape views of snowed mountain peaks, cliffs, rivers and valleys. These camera movements exceed natural human perception because these are views unattainable to the naked human eye. The IMAX panoramic vision induces a sensorial shock in the spectator, similar to the changes in perspective experienced by train-travellers of the $19^{\text {th }}$ century (Acland, 1998). Charles R. Acland suggests that the mode of perception enacted by the IMAX spectator, instead of being detached from the visual field, as in railway travel, is immersed within the panoptic field of the giant screen. This is what Acland calls panoramic realism, in which the stunning films of IMAX and the special viewing situation reignite the early experience of filmic realism - the shock of movement and the sensation of "being there" (1998, p. 430). Panoramic realism can be seen as a form of perceptual realism, one that focuses on perceptual landscape immersion. The immersive larger-than-life space of the IMAX theatre causes human sight to be merged into filmic and architectural space (Acland, 1998, p. 430). Tim Recuber suggests that these technological and

\footnotetext{
${ }^{1}$ The phantom ride is a camera movement made famous by travel ride films in which the camera is positioned at the front of a train or moving vehicle.

${ }^{2}$ See: www.imax.com.
} 
architectural devices facilitate a more intense and "absorbing" sensory experience for the spectator $(2007$, p. 316). For Acland, the theatre merges with the audience's senses. Recuber takes this idea forward conceiving the spectator's experience of the IMAX as a form of virtual immersion in which the spectator is "plugged" into filmic space (1998). For Recuber, the IMAX spectator becomes a cyborg, physically, materially and sensorially engaged with the film (2007). In this approach, extra-cinematic technologies such as 3D IMAX headsets and "GSS Sensory Seats" ${ }^{1}$ dissolve the distinction between human and machine, transforming the spectator's experience physically and viscerally as much as visually (Recuber, 2007). Moreover, the IMAX gigantic proportions and camera styles surpass all possibilities of sightseeing, giving the spectator a sense of totality, of constructing a "full view" of the world (Acland, 1998). Such totality inscribes a visual geography of the world that turns the experience of travelling into an ocular one, in as much as it discursively constructs it as attainable through technology. The IMAX entails an objective mode of vision modelled around an economy that favours high definition imagery, over-sized dimensions, overextended image data, hyper-realistic graphics and an over-stimulation of our audio-visual fields. It is overtly stimulating properties provide a sensory experience of film based on visceral response, vertiginous spatial references as well as visually immersive surroundings.

This combination of sensuously exhilarating stimuli in the cinema echoes the Aroma Rama, the Smell-O-Vision as well as the shaking seats of the travel ride film, in their attempt to stimulate the senses through technology. More recently, the incorporation of extra-cinematic technologies in film has upgraded what seems to be a mimesis of real life sensory perception. It seems as if cinematic technologies such as IMAX and IMAX 3D were in fact moving towards the Bazinian myth of total cinema (Acland, 1998). Acland writes:

Its goal is one of simulation, of hyper-realism, of producing images so real that they offer an illusion of material presence, and of creating the sensation of movement for its spectators. (1998, p. 430)

These hyper-realistic and immersive technologies in the cinema have been further developed in what is branded as 4D and 5D Cinema Theatres. The 4D films encompass tri-dimensional vision with interactive technologies such as D$\mathrm{BOX}^{2}$ seats, which are integrated systems that incorporate motion effects specifically programmed for each scene of the film. In 5D cinemas, sensorial immersion is further provoked by additional atmospheric effects such as wind, fog, mist, rain, snow, bubbles and light effects inside the theatre. This is combined with seat effects that poke the spectator's back or neck, spray water over and tickle the legs. While seating on a DBOX, the spectator moves in synchronic motion with the film, shaking with rumbling explosions and moving along car chases. This is enabled by a platform or seat that uses different movements and vibrations to

\footnotetext{
${ }^{1}$ The GSS sensory seats are a system that interprets low frequencies from a film's soundtrack into vibrations produced by devices implanted in seat backs (Recuber, 2007).

${ }^{2} \mathrm{DBOX}$ is a brand that manufactures and designs motion systems for the cinema industry.
} 
simulate the action on the film. DBOX technologies are branded as a "multisensorial revolution" ${ }^{1}$. It can be seen how new technologies attempt to incorporate aspects of embodied sensation in the cinematic experience.

\section{Travelogues in 3D: Hyper-Realism and Stereoscopy}

IMAX 3D travelogues entail the visual apprehension of volume, depth and perspective as essential aspects of the spectator's experience. These films explore a variety of themes, from trips to the ocean, outer space or the pre-historic past, produced with computer-generated graphics. Some examples are Howard Hall's Deep Sea 3D (2006) and Under the Sea 3D (2010), Luke Cresswell and Steve McNichol's Wild Ocean 3D (2008), Bayley Silleck's Cosmic Voyage (1996), Tony Myers' Hubble 3D (2010), Island of Lemurs: Madagascar (2014) by director David Douglas, IMAX T-Rex: Back to the Cretaceous (1998) by Brett Leonard and Dinosaurs 3D: Giants of Patagonia (2007) by Marc Fafard.

In IMAX 3D, stereoscopic vision allows the spectator to experience a form of cinematic immersion in which places are witnessed as material presence. Stereoscopic vision and tri-dimensional cinema are closely connected to the sense of touch (Clarke and Doel, 2005, pp. 53-54). These technologies present a visual volume that challenge optical perception by reproducing the visual changes of perspective that are perceived when looking at an object. Their attempt to mimic human perception brings the spectator into a closer relationship to the visual space of the image. According to David B. Clarke and Marcus A. Doel, the capacity of the stereoscope to visually bring forward the volume of an object gave it a tactile quality (2005). The impression of solidity that it provides turns vision tactile and fuses the optical with the "real" (Clarke and Doel, 2005, pp. 53-54). This tactility is associated with an illusion of volume and perspective. This is what Miriam Ross termed "stereoscopic realism", a feature that allows the spectator to feel the material presence of visual space through tri-dimensional images (2015, p. 72). This mode of vision is emphasized in IMAX 3D films, in which high-resolution images offer enough visual details that make the image appear palpable and tactile.

However, the tactility of the IMAX 3D offers an optical tactility instead of a haptic one. Laura Marks conceptualises haptic visuality as a mode of vision in which proximity allows the spectator to sense through the surface of an image (2000). For Marks, the most important difference between optical forms of vision and tactility is proximity. Haptic vision requires being near the object it apprehends, while optical modes of vision require enough distance from the object seen $(2000$, p. 162). As the stereoscope, it relies on a demarcated sense of distance to convey its optical illusion. The realistic illusion depends on the distance between the image and the viewer, and more specifically on a relational distance between each eye of the viewer and the image. In that sense, the stereoscope creates an effect of emulating physical proximity, thus "the desired effect of the stereoscope was not simply likeness, but immediate, apparent tangibility" (Crary,

\footnotetext{
${ }^{1}$ The slogan "multi-sensorial revolution" can be found in their website: DBOX website: http://www.d-box.com/en/the-mfx-technology.
} 
1992, pp. 122-124). The visual apprehension of texture remains distant from the surface of the object it apprehends. This points at the difference between vision and tactile experience. Merleau-Ponty writes:

In visual experience, which pushes objectification further than does tactile experience, we can, at least at first sight, flatter ourselves that we constitute the world, because it presents us with a spectacle spread out before us at a distance, and gives us the illusion of being immediately present everywhere and being situated nowhere. Tactile experience, on the other hand, adheres to the surface of our body, we cannot unfold it before us, and it never quite becomes an object. (1962, p. 369)

On the other hand, haptic forms of vision bring the spectator closer, to a point where texture and surface become form, and sensation of form (Marks, 2000, p. 162). Tri-dimensional images entail a mode of vision that does not rely on closeness or proximity, qualities intrinsic to the sense of touch. Instead, optical tactility is implicated in the visual display of texture and a precise detail of visual volume. In other words, it privileges the representational power of the image instead of its material presence, as in haptic vision (Marks, 2000, p. 162). Tridimensional visual technologies offer a hyper-realistic representation of volume and perspective, often dismissing the sensations ascribed to its material presence. Antonia Lant describes this lack of material contact in her writings about haptical cinema as the eye's pleasure to linger over a surface without being able to touch or move closer to the object seen (Lant, 1995, p. 30).

Thomas Elsaesser writes that 3D technologies are changing the spectator's embodied experience of virtual environments and spatio-temporal orientation (2013, p. 221). He argues that the recent re-incorporation of 3D technologies in the cinema represents a second failure for the film's industry initiative to counter-act the growing competition on internet television systems, such as Netflix (Elsaesser, 2013). 3D technologies are permeating home based entertainment systems, from video games to home theatres. This seems to emphasize the experience of immersion while increasingly becoming a naturalized technology (Elsaesser, 2013, p. 221). In other words, although 3D technologies present audio-visual environments that are rich in data, they aim to simulate its own invisibility and pass unnoticed by the user.

\section{Conclusions}

The travelogue film has employed multiple techniques to convey a sense of realism and translate the embodied experience of travel through film. The mimetic drive in the history of the genre can be seen in the perceptual realism of travel rides and immersive IMAX films. Some of the techniques discussed above are aerial camera movements, extra-cinematic technologies such as immersive screens and stereoscopic vision as well as long takes and first person narration. From these, stereoscopy is perhaps the one that is more often associated with the culmination of Bazinian teleology (Ross, 2015, p. 78). However, even if 
stereoscopy offers depth relations that are more faithful to real life perception than flat screens, its simulation of tri-dimensional environments is still limited. Stereoscopic realism as well as the panoramic realism of aerial camera movements conceives of perception through a visual logic. Although the travelogue film genre has explored the aesthetics of embodied experience, the affective dimension of embodied and synaesthesic modes of spectatorship have been largely missed by focusing on the mechanisation of sensorial stimuli. This is not exclusive of recent developments in cinema technology but has rather been consistent with the emergence and development of visual devices throughout the history of film. The myth of total cinema as the complete reproduction of reality points at the question of how is perception constituted by embodied experience and in what ways this experience might be translated to cinematic language. In order to construct a more holistic form of cinema we need to approach the cinematic experience phenomenologically, as an embodied, perceptual process; and take into account the subtle affective changes that occur inter-sensorially and synaesthetically during the experience of watching a film. In the future, it might not be fully immersive, virtual reality systems that will bring spectators closer into Bazin's myth of total cinema, but a cinema that explores perceptual reality as it is embodied.

\section{References}

Acland, C. R. (1998). IMAX Technology and the Tourist Gaze. Cultural Studies, 12(3), 429-445.

Altman, R. (2006). From Lecturer's Prop to Industrial Product: The Early History of Travel Films. In J. Ruoff (Eds.), Virtual Voyages: Cinema and Travel (61-78). London: Duke University Press.

Andrew, D. (1973). Critics: André Bazin. Film Comment, 9(2), 64-68.

Andrew, D. (2004). Foreword. In A. Bazin (Eds.), What is Cinema? Vol. I. London: University of California Press.

Auerbach, J. (2007). Body Shots, Early Cinema's Incarnations. Berkeley: University of California Press.

Barker, J. M. (2009). The Tactile Eye: Touch and the Cinematic Experience. London: University of California Press.

Bazin, A. (1967a). The Myth of Total Cinema. In A. Bazin, What Is Cinema? Vol. 1 (17-22), (H. Gray, Trans.). London: University of California Press.

Bazin, A. (1967b). The Evolution of the Language of Cinema. In A. Bazin, What Is Cinema? Vol. 1 (23-40), (H. Gray, Trans.). London: University of California Press.

Bazin, A. (1967c). The Virtues and Limitations of Montage. In A. Bazin, What Is Cinema? Vol. 1 (41-52), (H. Gray, Trans.). London: University of California Press.

Bazin, A. (1967d). The Ontology of the Photographic Image. In A. Bazin, What Is Cinema? Vol. 1 (9-16), (H. Gray, Trans.). London: University of California Press.

Bazin, A. (1967e). Theater and Cinema Part Two. In A. Bazin, What Is Cinema? Vol. 1 (95-124), (H. Gray, Trans.). London: University of California Press.

Bazin, A. (2014). Cinerama: A bit late. In D. Andrew (Eds. \& Trans.), André Bazin' New Media (220-226). Oakland, CA: University of California Press. (Original work written between 1952 and 1958)

Bruno, G. (2002). Atlas of Emotion, Journeys in Art, Architecture and Film. New 
York: Verso.

Bruzina, R. (2012). Phenomenology. The Journal of Speculative Philosophy, 26(2 Special Issue with the Society for Phenomenology and Existential Philosophy), 222-246.

Bruzzi, S. (2006). New Documentary (2nd ed.). London: Routledge.

Buck-Morss, S. (1994). The Cinema Screen as Prosthesis of Perception: A Historical Account. In N. Seremetakis (Eds.), The Senses Still (45-63). London: University of Chicago Press.

Clark, D. B., \& Doel, M. A. (2005). Engineering Space and Time: Moving Pictures and Motionless Trips. Journal of Historical Geography, 31, 41-60.

Comolli, J.-L. (1980). Machines of the Visible. In T. de Lauretis, \& S. Heath (Eds.), The Cinematic Apparatus (121-142). New York: St. Martin's Press.

Comolli, J.-L. (2015). Technique and Ideology: Camera, Perspective, Depth of Field. In J.-L. Comolli (Eds.), Cinema Against Spectacle. Technique and Ideology Revisited (D. Fairfax, Trans. \& Intr.). Amsterdam: Amsterdam University Press. (Original work published 1971-72)

Crary, J. (1992). Techniques of the Observer (7th ed.). MIT Press.

Crary, J. (1994). Unbinding Vision. October, 68(Spring), 21-44.

de Luca, T. (2011). Gus Van Sant's Gerry and Visionary Realism. Cinephile, The University of British Columbia's Film Journal, 7(2), 43-50.

Elsaesser, T. (2013). The "Return" of 3-D: On Some of the Logics and Genealogies of the Image in the Twenty-First Century. Critical Inquiry, 39(Winter), 217-246.

Fielding, R. (1970). Hale's Tours: Ultra-realism in the Pre-1910 Motion Picture. Cinema Journal, 10(1), 34-47.

Friday, J. (2005). Bazin's Ontology of Photographic and Film Imagery. The Journal of Aesthetics and Art Criticism, 63(4), 339-350.

Friedberg, A. (1991). Les Flâneurs du Mal(1): Cinema and the Postmodern Condition. PMLA, 106(3), 419-431.

Gallese, V. (2001). The "Shared Manifold" Hypothesis: From Mirror Neurons to Empathy. Journal of Consciousness Studies, 8(5), 33-50.

Gallese, V. (2005). Embodied simulation: from neurons to phenomenal experience. Phenomenology and the Cognitive Sciences, 4, 23-48.

Gallese, V., \& Sinigaglia, C. (2011). What is so special about embodied simulation? Trends in Cognitive Sciences, 15(11), 512-519.

Gallese, V., \& Guerra, M. (2012). Embodying movies: Embodied simulation and film studies. Cinema, 3, 183-210.

Giralt, G. F. (2010). Realism and Realistic Representation in the Digital Age. Journal of Film and Video, 62(3), 3-16.

Grierson, J. (2002). First Principles of Documentary (1932). In C. Fowler (Eds.), The European Cinema Reader (39-44). London: Routledge.

Griffiths, A. (2006). Time Traveling |MAX Style: Tales from the Giant Screen. In J. Ruoff (Eds.), Virtual Voyages, Cinema and Travel (238-258). London: Duke University Press.

Gubern, R. (2014). Historia del Cine (History of Cinema). Barcelona: Anagrama.

Gunning, T. (1989). An Aesthetic of Astonishment: Early Film and the Incredulous Spectator. Art and Text, 34(Spring), 31-45.

Gunning, T. (2000). The Cinema of Attraction: Early Film, Its Spectator, and the Avant-Garde. In T. Miller, \& R. Stam (Eds.), Film Theory: An Anthology. Oxford: Blackwell.

Heidegger, M. (1962). Being and Time. (J. Macquarrie, \& E. Robinson, Trans.). New York: Harper \& Row Publishers. (Original work published 1927) 
Heider, K. G. (1976). Ethnographic Film, Revised edition. Austin: University of Texas Press.

Heider, K. G. (1997). Seeing Anthropology, Cultural Anthropology through Film. Boston: Allyn and Bacon.

Husserl, E. (1960). Cartesian Meditations: An Introduction to Phenomenology. (D. Cairns, Trans.). The Hague, London: Martinus Nijhoff Publishers. (Original work published 1931)

Husserl, E. (1973). Logical Investigations. (J. N. Findlay, Trans.). London: Routledge. (Original work published 1913)

Lant, A. (1995). Haptical Cinema. October, 74(Autumn), 45-73.

Massumi, B. (2002). Parables of the Virtual, Movement, Affect, Sensation. London: Duke University Press.

Marks, L. U. (2000). The Skin of The Film, Intercultural Cinema, Embodiment, and the Senses. London: Duke University Press.

Marks, L. U. (2002). Touch, Sensuous Theory and Multisensory Media. Minneapolis: University of Minnesota Press.

Merleau-Ponty, M. (1962). Phenomenology of Perception. (C. Smith, Trans.). London: Routledge. (Original work published 1945)

Musser, C. (1994). The Emergence of Cinema: the American Screen to 1907. London: University of California Press.

Neumann, D. (2008). Instead of the Grand Tour: Travel Replacements in the Nineteenth Century. Perspecta, 41(Grand Tour), 47-53.

Peterson, J. L. (2013). Education in the School of Dreams: Travelogues and Early Nonfiction Film. London: Duke University Press.

Pouliot, L., \& Cowen, P. S. (2007). Does Perceived Realism Really Matter in Media Effects? Media Psychology, 9, 241-259.

Rabinovitz, L. (2006). From Hale's Tours to Star Tours: virtual voyages, travel ride films, and the delirium of the hyper-real. In J. Ruoff (Eds.), Virtual Voyages, Cinema and Travel (42-60). London: Duke University Press.

Recuber, T. (2007). Immersion Cinema: The Rationalization and Re-enchantment of Cinematic Space. Space and Culture, 10, 315-330.

Reeves, H. (1999). This is Cinerama. Film History, 11(1 Film Technology), 85-97.

Rosen, P. (2003). History of Image, Image of History: Subject and Ontology in Bazin. In I. Margulies (Eds.), Rites of Realism: Essays on Corporeal Cinema (42-79). London: Duke University Press.

Ross, M. (2015). New Realisms. In M. Ross (Eds.), 3D Cinema: Optical Illusions and Tactile Experiences (72-89). Hampshire: Palgrave Macmillan.

Ruoff, J. (2006). Virtual Voyages: Cinema and Travel. London: Duke University Press.

Rushton, R. (2011a). The Reality of Film: Theories of Filmic Reality. Manchester University Press.

Rushton, R. (2011b). Post-Classical Hollywood Realism and "Ideological Reality". Cinephile, The University of British Columbia's Film Journal, 7(2), 15-21.

Sartre, J.-P. (1956) Being and Nothingness: An Essay of Phenomenological Ontology. (H. E. Barnes, Trans.). New York: Philosophical Library. (Original work published 1943)

Schivelbusch, W. (1977). The Railway Journey, The Industrialization of Time and Space in the 19th century. Los Angeles: University of California Press.

Shaviro, S. (1993). The Cinematic Body. Minneapolis: University of Minessota Press.

Shaviro, S. (2007). Emotion Capture: Affect in Digital Film. Projections, 1(2), 63-82.

Sobchack, V. (1992). The Address of The Eye. A Phenomenology of Film Experience. New Jersey: Princeton University Press. 
Soltani, A. (2008). CineSensory: A Filmic Design for Mapping Haptic Space. International Design and Cinema Conferenc. Istanbul, Turkey. November 19-22.

Staples, A. J. (2006). "The Last of the Great (Foot-Slogging) Explorers": Lewis Cotlow and the Ethnographic Imaginary in Popular Travel Film. In J. Ruoff (Eds.), Virtual Voyages: Cinema and Travel (195-218). London: Duke University Press.

Urry, J. (1990). The Tourist Gaze. London: Sage Publications.

Varela, F. J. (1996). Neurophenomenology, A Methodological Remedy for the Hard Problem. Journal of Consciousness Studies, 3(4), 330-349.

Wikgren, M. (2005) Critical Realism as a Philosophy and Social Theory in Information Science? Journal of Documentation, 61(1), 11-22. 
